\title{
ИССЛЕДОВАНИЕ ОТВЕТА В-ЛИМФОЦИТОВ СЕЛЕЗЕНКИ МЫШЕЙ НА ВОЗДЕЙСТВИЕ ПРИРОДНЫХ ДВУСПИРАЛЬНЫХ РНК
}

\author{
Е.С. Цыпленкова, Е.А. Вязовая, Е.Д. Даниленко
}

ФБУН ГНЦВБ «Вектор» Роспотребнадзора, 633010, г. Бердск ул. Химзаводская, 9

DOI:10.19163/MedChemRussia2021-2021-440_E-mail:tsyplenkova_es@vector.nsc.ru

Экстренная профилактика остается эффективным методом защиты населения от инфекций, одним из средств которой являютсяинтерфероногены [1]. Известно, что стимуляция синтеза эндогенного интерферона - более эффективный и естественный способ лечения, чем прием его извне. Препарат Ридостин, действующим началом которого являются дрожжевыедвуспиральные РНК (дсРНК), - индуктор интерферона с доказанной эффективностью. Несмотря на довольно значительный опыт применения Ридостина, механизмы его действия до сих пор детальноне изучены. Целью данного исследования являлась оценка влияния дсРНК на некоторые параметры активности В-лимфоцитов при введении ее в клеточную культуру селезенки.

Материалы и методы. Исследования проведены на клетках селезенкиинтактных самокмышей линии Balb/c возрастом 8-12 недель. Суспензию клеток получали, гомогенизируяселезенкув среде ДМЕM с 10\%FCS.После лизиса эритроцитов клетки инкубировали с препаратом двуспиральной РНК в дозе 2,5 мкг/мл в течение 22 ч при $37^{\circ} \mathrm{C}$. В качестве контроля использовали инкубированные клетки без препарата.Далее клетки окрашивали мечеными флуорохромамимоноклональными антителами к маркерам CD19, CD86, CD69 и анализировали методом проточной цитометрии.

Результаты. Показано, что дсРНК повышает экспрессию маркеров активации на поверхности В-лимфоцитов. Общее количество CD19+-клетокв регионе составило 18-23\%. Доля клеток, несущих маркеры CD19+CD86+, в опытной группе достовернопревысила контрольный уровень (соответственно, $21,9 \pm 1,4 \%$ и $15,3 \pm 1,1 \%, p \leqslant 0,05)$. Статистически значимо увеличилась и

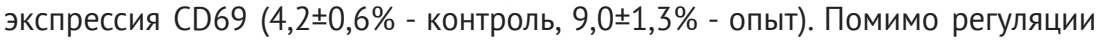
активности В-лимфоцитов, отмечено значимое увеличение экспрессии активационных маркеров во всем исследуемом клеточном регионе.Таким образом, дсРНК оказывает прямое стимулирующее действиена функциональную активность иммунокомпетентных клеток селезенки за счет усиления экспрессии маркера CD86, как известно [2], запускающего процесс костимуляции B-и Т-лимфоцитов, а также увеличения экспрессии молекулы CD69, регулирующей процессы миграции лимфоцитов.

\section{Литература}

1. Ю. Л. Мизерницкий, Медицинский совет. 2015, №14, 81-83

2. P. Zhang, M. Martin, Q. Yang and et al., Infect Immun. 2004, 72(2), 637-644 